\title{
Discussion on Religious Practice in Counseling: a Preliminary Survey
}

\author{
Assoc. Prof. Dr. Salasiah Hanin Hamjah \\ Nadhirah Muhamad Arib \\ Department of Dakwah \& Leadership Studies, \\ Faculty of Islamic Studies, National University of Malaysia (UKM), \\ Email : salhanin@ukm.edu.my
}

\section{Doi:10.5901/mjss.2015.v6n6s5p394}

\section{Abstract}

Religious practice is essential in every faith. This practice reflects the strength of conviction and adherence to one's professed faith. Studies in the West have shown the necessity to discuss religious issues in counseling and this method is accepted for implementation in counseling sessions with clients as religion and life are inseparable. The purpose of this present research is to identify the appropriate type of religious practice to be discussed in counseling sessions with clients. Its aim is also to study the appropriate level to apply the related religious practice issue in the counseling process and to analyse the problems arising in implementing such discussions. The research methodology used is survey method using questionnaire. Selection for research uses the convenience sampling $(N=50)$ method. Research results are analysed by statistical description. Findings show that there is a need to discuss religious practice in counseling. Among the types of religious practice appropriate to be discussed are supplication (doa), reciting al-Quran, prayers (solah) and sending prayers and salutations (salawat) upon the Prophet Muhammad (pbuh). This research finds that there are problems in discussion of religious practice with clients in counseling such as uncooperative client, counselor feels client is uncomfortable, disinterested client, client is not ready and counselor thinks religious practice is a sensitive matter.

Keywords: religious practice, counseling, necessity, problem, cooperation

\section{Introduction}

Before studying the aspect of religious practice discussed in counseling sessions between the counselor and client, it is first necessary to generally discuss the application of religious or spiritual element in counseling. In the early developmental phase of counseling, the application of religious values in counseling was considered a violation of counseling ethics. However, it was found later that many human life issues were settled through religious solutions, thus there emerged efforts to apply religious or spiritual element in counseling. There are many grounds given on the importance of applying religious or spiritual element in counseling. Corey (2003) found that religion and spirituality are often part of the client's problem, but can also be part of the client's solution. Spiritual and religious values can play a major part in human life, spiritual values should be viewed as a potential resource in therapy rather than as something to be ignored.

In the same regard, Benjamin \& Lobby (1998) also explained the importance of applying religious or spiritual aspect in counseling for the reason that many clients believe that the religious or spiritual aspect is integrally connected to personal growth. Souza (2002) as well as Horfman \& Walach (2011) stated that the application of the religious or spiritual aspect coincides with the importance of diversity in counseling and it is essential that a counselor understands the spiritual aspect as an aspect of client diversity. Day (2010) explained, "A body of recent research has noted some positive impact of spirituality on well-being. Across a broad array of cultural settings and populations, religion and spirituality have often been found to be contributing factors to life satisfaction, sense of personal efficacy, successful coping, and self-esteem."

Another reason for the importance of religious or spiritual application in counseling is that it may have therapeutic value in the extent that incorporation helps counselors to support clients in connecting to others, moving outside of themselves, and contributing to the common good (Blando, 2006). In addition, the application of religious element in counseling is also important for clients who voluntarily wish to discuss the religious aspect during counseling. Rose, Westefeld, and Ansley (2001) surveyed 74 individuals who were receiving counseling and found that $55 \%$ of them wanted to discuss religious or spiritual issues because they believed religion and spirituality were essential for healing and growth (27\%), were personally important (22\%), were central to human personality, behavior, and worldview (15\%), and were 
relevant to problems (5\%). Some of the respondents felt their preference would change throughout different contexts, indicated by $22 \%$ of respondents reporting that their preference in discussing religion and/or spirituality was dependent on other factors such as relevance to problems (10\%), only if it was a spiritual issue, but not religious (8\%), or depending on the qualities of the counselor (5\%). Belaire and Young (2000) studied the influences of spirituality on counselor selection and found that while client spirituality may have less influence over counselor selection, counselor ability to effectively implement religion and spirituality into counseling has an effect on client preference of counselors. Post and Wade (2014) found in their study that the majority of clients indicated that religious concerns are an appropriate topic for group counseling and reported a preference to discuss religious and spiritual concerns with their group. All the findings clearly show that Western scholars recognise the importance of applying religious or spiritual discussion in counseling sessions.

Previous studies have also examined the religious or spiritual aspect and counseling. For example, a study by Cornish et al. (2012) found that spiritual interventions were very appropriate to be applied in counseling. In addition, a study by Burke et.al (1999) also proved that there were studies conducted on religion and counseling. Survey data of the general population, counselors and counselor educators indicate that spiritual and religious issues are therapeutically relevant, ethically appropriate and potentially significant topics in counseling and counselor education. This finding is found to be in line with studies by Smith (2006) as well as by Horfman \& Walach (2011) which found that the majority of respondents concur on the importance of discussing the spiritual aspect with clients in counseling sessions. The majority of clients who were receiving counseling with elements of religiosity included indicated that it had been very helpful in making progress toward goals $(73.5 \%)$, while $16.3 \%$ reported the integration of religiosity had been moderately helpful, and $10.2 \%$ indicating it was neither helpful nor unhelpful. No respondents reported that the integration of religiosity in counseling was unhelpful (Tiffany 2011). This kind of research was also conducted in Malaysia such as studies by Mohd Syukri (2010), Nadiah (2009), Salasiah (2010), Salasiah et al. (2012) and Nurul Ain (2006). These studies discussed more of techniques or methods used and the importance of applying the religious aspect in the counseling process.

The above discussion explains that studies which directly focus on specific religious practice in counseling are yet to be done. Hence, this study is for the purpose of determining whether discussion of religious practice is being applied by the counselor in counseling sessions. If affirmative, then what types of religious practice are appropriate for counseling sessions with clients? Which level is appropriate for applying issues relating to religious practice in counseling? And, what are the problems faced in applying the element of religious practice in counseling?

Religious practice or ibadah (worship) is an important matter in the life of a Muslim consistent with the purpose of human creation on this earth as stated in al-Quran that Allah SWT created the jin (genies and spirits) and mankind in order that they praise and worship Him (al-Zariyat 51:56). Ibadah (worship) is one of the main components in Islamic teachings other than aqidah (faith) and akhlaq (moral character). It symbolizes the devotion of a slave for his Creator. It has a wide meaning. Religious practice in Islam is understood as all aspects which cover the meaning submission to the commands and avoiding all the prohibitions of Allah SWT (al-Ghazali, 1994). According to al-Qaradawi (1993) religious practice connotes complete devotion, submission, obedience and humility to Allah SWT by compliance with His rules and commandments as established in al-Quran and Hadith of His Messenger (pbuh). Religious practice directly connects a slave with his Creator and returns him to the original purpose of creation, that is, to worship Allah SWT (al-Ghazali, 2000). Religious practie in Islam is divided into two, general and specific. General religious practice encompasses every action done to achieve God's pleasure such as virtuous conduct, respect for parents and so on. It also means a slave's intentional action in compliance with Allah's will. Specific religious practice means certain practices which a slave is obliged to do as training to prove his proper compliance of the five tenets of Islam, which are: declaration of faith, prayers, zakah (alms), fasting and hajj. It also encompasses commonly known religious obligations such as charity, umrah and tilawah al-Quran (al-Bayanuni 1984; al-Qaradawi 1993; Mulhim 2004; Salasiah \& Noor Shakirah (2014)

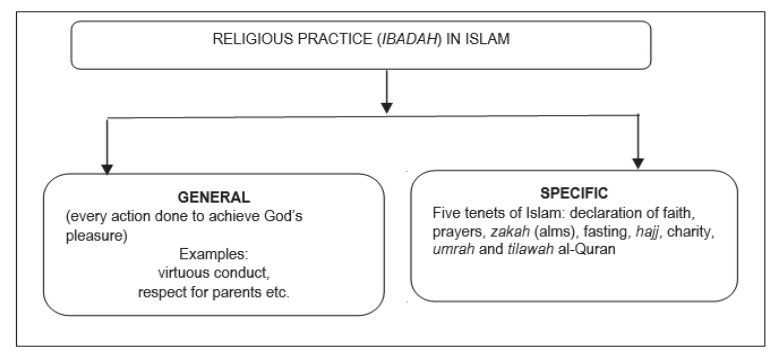

Diagram 1: Islamic Religious Practice 
There is strong justification for religious practice to be discussed in counseling sessions as the aim of counseling is to assist the client to achieve peace of mind and successfully overcome or manage problems in life. Islamic religious practice commanded by Allah SWT to be implemented by the Muslim Ummah has the potential to affect man's life, for example, the practice of remembrance (zikir) of Allah may bring peace and tranquility (al-Ra'd: 28), prayers (solah) has been found to deter man from doing evil (al-Ankabut: 45), and supplication (doa) may bring the self closer to Allah SWT (al-Baqarah:186). According to Abdullah as-Sirri (1996), comprehensive religious parctice enables one's personal capacity to develop into a great individual in dual roles as a slave of Allah SWT and his vicegerent on earth. Mohd Sabri, Syed Najmuddin \& Ab.Halim (2009) were of the opinon that religious practice such as zikir, doa and recitation of al-Quran may contribute to raising individual self-awareness. The above views are parallel with the views of Western scholars such as Hathaway \& Pargament (1991) who stated that religious resources identified as commonly used in times of stress include prayer, solitary activities, faith in God, and guidance from clergy, which are representative of the spiritual, cognitive, behavioural, and social aspects of faith.

\section{Research Objective}

Thus, realizing the importance of applying the element of religious or spiritual practice in counseling, this present research is done to achieve the following objectives:

1. To identify the types of religious practice appropriate for discussion with clients in counseling sessions;

2. To study the appropriate level to apply issues related to religious practice in the counseling process;

3. To analyse the problems faced in discussing religious practice with clients.

\section{Research Methodology}

This research is designed as a survey study. The date collection instrument used is questionnaire. 50 respondents comprising of registered counselors have been selected as research sample. Respondents are also counseling practitioners in the Klang Valley of Malaysia. This location is selected as Kuala Lumpur, the capital city of Malaysia is situated there and Klang Valley is also in the rapidly developing state of Selangor. Klang Valley is also the destination of many individuals who migrate from other states in Malaysia including Sabah, Sarawak, Kelantan, Trengganu, Perak, Penang, Kedah, Malacca, Negri Sembilan, Johore and Pahang. Selection of respondents is through convenience sampling due to difficulty in gaining respondents' cooperation if simple random sampling was done. A pilot study was done to verify reliabilty of research instrument. Data obtained was analysed using SPSS to obtain alpha cronbach value. Overall alpha cronbach value obtained for variables is 0.972 . As it exceeds 0.6 , this research instrument has high consistency and reliability. Data from questionnaires are analysed using SPSS and presented in the form of percentage, frequency and mean.

\section{Research Results and Discussion}

This research is done to identify the types of Islamic religious practice appropriate to be applied in counseling sessions. Findings show that many among respondents ( $88 \%$ agree and strongly agree) to apply religious practice to clients: fard solah (obligatory prayers) (mean=4.26), doa (supplication) (mean=4.24) followed by reciting of al-Quran (mean=4.12) and salawat (sending blessings and salutations upon the Prophet pbuh) (mean=4.08). The type of religious practice least applied is hajj (pilgrimage) (mean=3.12). The reason for this is that it is only discussed in certain cases such as when client is financially stable, seriously intends to tawbah (repent) and wishes to find peace of mind through ibadah (worship) to Allah SWT.

Table: Types of religious Practice applied in Counseling

\begin{tabular}{lcccccc}
\hline Types of religious practice & Never & Once in a while & Sometimes & Usually & Always & Mean \\
\hline I apply fard solah (obligatory prayers) to the client. & 1 & 1 & 4 & 22 & 22 & 4.26 \\
& $(2.0 \%)$ & $(2.0 \%)$ & $(8.0 \%)$ & $(44.0 \%)$ & $(44.0 \%)$ & \\
& 2 & 3 & 14 & 21 & 10 & 3.68 \\
I apply sawm (fasting) to the client. & $(4.0 \%)$ & $(6.0 \%)$ & $(28.0 \%)$ & $(42.0 \%)$ & $(20.0 \%)$ & \\
& 4 & 8 & 20 & 14 & 4 & 3.12 \\
I apply haij (pilgimage) to the client. & $(8.0 \%)$ & $(16.0 \%)$ & $(40.0 \%)$ & $(28.0 \%)$ & $(8.0 \%)$ & \\
\hline
\end{tabular}




\begin{tabular}{lcccccc}
\hline Types of religious practice & Never & Once in a while & Sometimes & Usually & Always & Mean \\
\hline I apply sunnah awwabin solah (prayers of the oft- & 4 & 6 & 22 & 14 & 4 & 3.16 \\
repentant, before and after fard solah) to the client. & $(8.0 \%)$ & $(12.0 \%)$ & $(44.0 \%)$ & $(28.0 \%)$ & $(8.0 \%)$ & \\
I apply sunnah tawbah solah (repentance) to the client. & 2 & 1 & 12 & 20 & 15 & 3.90 \\
& $(4.0 \%)$ & $(2.0 \%)$ & $(24.0 \%)$ & $(40.0 \%)$ & $(30.0 \%)$ & \\
& 2 & 1 & 7 & 28 & 12 & 3.94 \\
& $(4.0 \%)$ & $(2.0 \%)$ & $(14.0 \%)$ & $(56.0 \%)$ & $(24.0 \%)$ & \\
I apply sunnah hajah solah (intent/need) to the client. & 2 & 1 & 13 & 23 & 10 & 3.78 \\
& $(4.0 \%)$ & $(2.0 \%)$ & $(26.0 \%)$ & $(46.0 \%)$ & $(20.0 \%)$ \\
I apply sunnah tahajjud solah ( night prayer after sleep) to & 2 & 2 & 6 & 27 & 13 & 3.94 \\
the client. & $(4.0 \%)$ & $(4.0 \%)$ & $(12.0 \%)$ & $(54.0 \%)$ & $(26.0 \%)$ & \\
I apply zikr (remembrance of Allah) to the client. & 2 & 1 & 3 & 21 & 23 & 4.24 \\
& $(4.0 \%)$ & $(2.0 \%)$ & $(6.0 \%)$ & $(42.0 \%)$ & $(46.0 \%)$ & \\
& 1 & 1 & 5 & 27 & 16 & 4.12 \\
I apply doa (supplication) to the client. & $(2.0 \%)$ & $(2.0 \%)$ & $(10.0 \%)$ & $(54.0 \%)$ & $(32.0 \%)$ \\
& 1 & 1 & 7 & 25 & 16 & 4.08 \\
I apply tilawah (reciting) al-Quran to the client. & $(2.0 \%)$ & $(2.0 \%)$ & $(14.0 \%)$ & $(50.0 \%)$ & $(32.0 \%)$ & \\
\hline
\end{tabular}

\section{Source: Questionnaire UKM 2010}

Research findings show that other than religious practice such as fard solah (mean=4.26), doa (mean=4.24), reciting alQuran (mean=4.12), salawat to the Prophet (pbuh) (mean=4.08) and performing hajj (mean=3.12), counselors also apply religious practice such as zikr (mean=3.94), sunnah hajah solah (mean=3.94), sunnah tawbah solah (mean=3.90), sunnah tahajjud solah (mean=3.78), fasting (min=3.68) and sunnah awwabin solah, before and after fard solah (mean=3.16).

These findings explain that counselors apply religious practice which covers basic Islamic practice to their clients. Fard solah is the most frequently applied in counseling sessions by counselors because it is a pillar of Islam and the first matter which will be brought to account on the Day of Judgement. Sunnah hajah solah, the leading sunnah prayer, is the next most frequently discussed in counseling sessions. This is appropriate with the fact that clients come fo counseling services in distress over the challenges of life's trials and tribulations. Hence, they need to perform sunnah hajah solah so that Allah may show them the way out of their difficulty as stated by Allah SWT in surah al-Talaq (65:2) which means whoever bears taqwa (fears and keeps his duty to Allah SWT), Allah will show him the way out ( of every difficulty). AlGhazali 's view (2000) is consistent with this verse when he suggested that Muslims should perform sunnah hajah solah in times of difficulty and pray for goodness in this worldly life and the hereafter.

Findings on religious practice such as solah (prayers) and doa (supplication) are discussed in counseling sessions in line with findings of a study by Saenz \& Waldo (2013) that many clients found prayer to be helpful and important in counseling. It was also found that clients who wanted their counselor to pray with them in session had higher selfreported levels of spirituality and religious commitment. Clients who preferred to have their counselor encourage out-ofsession prayer had mid-range levels of spirituality and religious commitment. Clients who preferred not to have prayer mentioned during their counseling session had lower levels of spirituality and religious commitment.

In addition, this research finds that zikr ( remembrance of Allah) scored the 5th highest mean (mean=3.94) among the types of religious practice frequently applied by counselors. This is so because counselors believe that clients who undergo counseling sessions are anxious and miserable and need zikr to calm down and attain peace of mind as stated in al-Quran that the hearts of believers will feel tranquil and peaceful in zikrullah (remembrance of Allah) (al-Ra'd 13:28). This finding is consistent with that by Nursaidatul Fasiha (2011) who studied the perception of students towards zikr as a human psychological therapy and found the majority of respondents responded well to zikr as the best therapy for attaining peace of mind.

This research is conducted to study the most appropriate level to apply the issue of religious practice in the counseling process. Research results find that respondents apply the aspect of religious practice at the end and follow-up level (mean=4.20), followed by the strategy selection and action plan level (mean=4.16). $88 \%$ of research respondents agree and strongly agree to discuss client's religious practice at the end and follow-up level because at this level clients are already beginning to function effectively, are independent and responsible (Ea Ah Meng, 2003). In addition, research respondents apply the issue of religious practice in counseling at the follow-up level because this is the final level in the counseling process. At this level, counselors get feedback from clients on the techniques and action plan implemented including the plan for religious practice (Maznah Baba \& Zainal Madon, 2003). 
Table 2: Level for Application of Religious Practice in Counseling Process

\begin{tabular}{lcccccc}
\hline Level for Application of Ibadah (worship) & $\begin{array}{c}\text { Strongly } \\
\text { Disagree }\end{array}$ & Disagree & $\begin{array}{c}\text { Not } \\
\text { Sure }\end{array}$ & Agree & $\begin{array}{c}\text { Strongly } \\
\text { Agree }\end{array}$ & Mean \\
\hline I apply ibadah aspect in counseling session at & 5 & 10 & 10 & 17 & 8 & 3.26 \\
building rapport level & $(10.0 \%)$ & $(20.0 \%)$ & $(20.0 \%)$ & $(34.0 \%)$ & $(16.0 \%)$ & \\
I apply ibadah aspect in counseling session at & 3 & 9 & 9 & 21 & 8 & 3.44 \\
problem exploring level & $(9.0 \%)$ & $(18.0 \%)$ & $(18.0 \%)$ & $(42.0 \%)$ & $(16.0 \%)$ & \\
I apply ibadah aspect in counseling session at level & 1 & 1 & 6 & 23 & 19 & 4.16 \\
of strategy selection and action plan & $(2.0 \%)$ & $(2.0 \%)$ & $(12.0 \%)$ & $(46.0 \%)$ & $(38.0 \%)$ & \\
I apply ibadah aspect in counseling session at the & 1 & 2 & 3 & 24 & 20 & 4.20 \\
end and follow-up level. & $(2.0 \%)$ & $(4.0 \%)$ & $(9.0 \%)$ & $(48.0 \%)$ & $(40.0 \%)$ & \\
\hline
\end{tabular}

Source: Questionnaire UKM 2010

$84 \%$ of research respondents agree and strongly agree on applying the element of religious practice at the level of strategy selection and action plan. The reason is that at this level the clients are able to list the options and strategies to be implemented, assess the options, and counselors encourage clients to implement their options (Maznah Baba \& Zainal Madon, 2003). According to researchers, this level is more suitable for applying religious practice because counselors suggest religious practice appropriate for the client's case and encourage the client to implement it. In the following counseling session, the counselor may assess implementation of the religious practice and study its effect on the client's life.

Research results also find that counselors apply the element of religious practice at the level of exploring the problem (mean=3.44). At this level, counselors use all their skills to explore client's issue (Sapora et al. 2002). After exploring, counselors will identify the source of the problem and match the problem with the appropriate type of religious practice for discussion as an alternative solution. Some counselors also apply religious practice at the level of building rapport even though this scored the lowest mean (mean=3.26) as at this level it is not so suitable to apply religious practice. In other words, it is too early to discuss religious practice when there is no rapport yet between counselor and client. In short, counselors need to use their wisdom to select the best level to discuss the issue of religious practice with their clients in the counseling process. Briefly, this finding explains that research respondents apply the element of religious practice at all levels in the counseling process. This also reflects that applying the element of religious practice is important and is accepted practice in counseling.

Further, another objective of this research is to analyse the problems encountered by respondents in applying religious practice in counseling. Research results find that there are five matters which cause difficulty to respondents in applying religious practice. These are: 'I feel client is not giving cooperation to discuss religious practice '(mean=3.32), "I feel that client is not comfortable discussing religious practice in counseling session '(mean=3.16), 'I feel that client is disinterested to discuss religious practice in counseling session." (mean= 3.12), "I feel that the client is not ready to discuss religious practice in counseling session' (mean=3.08), and 'My opinion is that the issue of religious practice is a sensitive matter ' (mean=3.00).

Briefly, this research finds that clients are not willing to cooperate, feel uncomfortable, are disinterested, are not ready and counselors consider the issue of religious practice as a sensitive matter not appropriate for discussion in counseling sessions. This finding is in line with a study by Rose, Westefeld, and Ansley (2001), which found that comparatively, a minority of clients (18\%) reported that they preferred not to discuss such topics in individual therapy for various reasons such as not being personally religious or spiritual and preferring to discuss these matters with a religious leader. Research on 74 individuals who were receiving counseling found that eighteen percent reported not wanting to discuss religious or spiritual issues because religious or spiritual issues are not currently important or relevant to problems (11\%), they prefer to discuss religious issues with the clergy (4\%), or they are unsure of their own beliefs (3\%). 
Table 3: Problems encountered in applying the religious practice aspect in counseling sessions

\begin{tabular}{lcccccc}
\hline $\begin{array}{l}\text { Problems faced while applying the religious practice } \\
\text { aspect }\end{array}$ & $\begin{array}{c}\text { Strongly } \\
\text { disagree }\end{array}$ & Disagree & $\begin{array}{c}\text { Not } \\
\text { sure }\end{array}$ & Agree & $\begin{array}{c}\text { Strongly } \\
\text { agree }\end{array}$ & Mean \\
\hline I feel that client feels uncomfortable to discuss & 0 & 14 & 16 & 18 & 2 & 3.16 \\
religious practice in counseling session. & $(0.0 \%)$ & $(28.0 \%)$ & $(32.0 \%)$ & $(36.0 \%)$ & $(4.0 \%)$ & 3.08 \\
I feel client is not ready to discuss religious practice & 1 & 18 & 15 & 16 & 0 & 3.08 \\
in counseling session. & $(2.0 \%)$ & $(36.0 \%)$ & $(30.0 \%)$ & $(32.0 \%)$ & $(0.0 \%)$ & 3.12 \\
I feel that client is disinterested to discuss religious & 1 & 20 & 14 & 14 & 1 & 3.12 \\
practice in counseling session. & $(2.0 \%)$ & $(40.0 \%)$ & $(28.0 \%)$ & $(28.0 \%)$ & $(2.0 \%)$ & 3.32 \\
I feel that client is not willing to cooperate to discuss & 2 & 24 & 13 & 10 & 1 & 3.32 \\
religious practice. & $(4.0 \%)$ & $(48.0 \%)$ & $(26.0 \%)$ & $(20.0 \%)$ & $(2.0 \%)$ & 3.00 \\
My opinion is that religious practice is a sensitive & 5 & 17 & 7 & 15 & 6 & 3.00 \\
issue. & $(10.0 \%)$ & $(34.0 \%)$ & $(14.0 \%)$ & $(30.0 \%)$ & $(12.0 \%)$ & \\
\hline
\end{tabular}

Source: Questionnaire UKM 2010.

Research results are also in line with findings by Brian (2010) which show that religion and spirituality should not only be of interest to therapists because the majority of clients prefer to discuss these topics when appropriate, but also because religion and spirituality are often the source of distress. In addition, these findings are also parallel to a study by Belaire and Young (2000) which found that clients who did not want a counselor who would address spirituality often claimed that they wanted counseling to be a time to address changing patterns, setting goals, and personal growth, and that religious or spiritual issues could be handled on their own time.

Other than clients feeling uncomfortable, are not ready, not cooperating and counselors consider religious practice a sensitive matter not suitable for discussion in counseling session, a study by Keating \& Fretz (1990) also found anxiety among clients when the issue of religious practice is brought up in counseling because of the possibility of counselor's negative reaction towards their beliefs. Clients not only fear that psychotherapists will respond negatively to their religious beliefs. Many clients who prefer not to discuss spiritual and religious issues in the counseling office identify fear as a factor limiting their ability to openly discuss religious and spiritual issues. Some clients are concerned about how therapists may respond to their beliefs, likely affecting client willingness to discuss spiritual issues (Rose et al., 2001). Further, the lack of emphasis by counselors to discuss the issue of religious or spiritual practice in counseling also cause clients to be less interested to discuss it. Because of this current lack of addressing religion and spirituality by counselors, clients were less willing and less likely to find it appropriate to discuss religion and spirituality in counseling sessions (Richards \& Bergin, 1997; Morrison et al. 2009).

Research results state that religious practice or ibadah (worship) is being discussed iin counseling by counselors who are research respondents. Religious practice discussed is basic Islamic practice including general and specific ibadah. This practice is suitable to be applied at all levels in the counseling process although the most frequently implemented by counselors is the end and follow-up level. Counselors report that they face some problems in implementing discussion of religious practice in counseling their clients. Research findings are summarised in the following diagram:

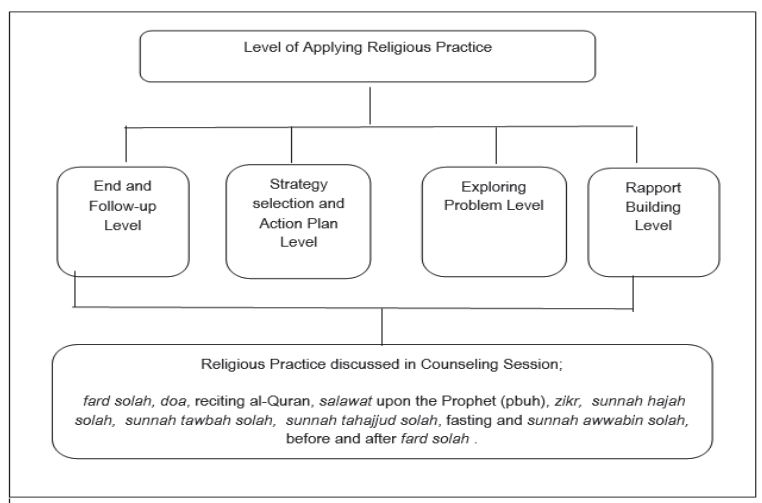

Diagram 2: Discussion of Religious Practice in Counseling 


\section{Conclusion}

Applying the element of religious practice in counseling has already been done by counselors in this research. Among the types of religious practice frequently discussed in counseling sessions are obligatory prayers (fard solah), supplication (doa), reciting al-Quran, sending blessings and salutations (salawat) upon the Prophet (pbuh), remembrance (zikr), prayers of need/intent ( sunnah hajah solah), prayers of repentance ( sunnah tawbah solah), night prayers (sunnah tahajjud solah), fasting (sawm) and prayers of the oft-repentant (sunnah al-awwabin solah) before and after obligatory prayers. In addition, this research also finds that the related issue of client's religious practice is discussed in counseling sessions at all levels in the counseling process, including at the end and follow-up level, strategy selection and action plan level, exploration of problem level and building rapport level. Both findings explain that applying the related issue of religious practice is already being implemented by registered counselors in the Klang Valley, Malaysia. Further, this research finds that problems faced in applying the religious element in counseling are that clients are uncooperative, feel uncomfortable, are disinterested, are not ready and counselors think that the issue of religious practice is too sensitive a matter to be discussed in counseling sessions. Nevertheless, these problems do not at all hinder counselors from applying the aspect of religious practice in counseling to help clients overcome or manage problems faced in order to achieve well-being in life.

\section{Acknowledgement}

This research received a grant from the National University of Malaysia (Universiti Kebangsaan Malaysia). Project Code UKM-GGPM-CMNB-027-2010 and AP-2014-020.

\section{References}

Abdullah As-Sirri (1996). The Secret of the Devout's Strength.Shah Alam : Wadah IImu.

al-Bayanuni, Muhammad Abu al-Fath (1984). al-Ibadah Dirasah Manhajiyyah Syamilah fi Dawi al-Kitab wa al-Sunnah. Kaherah : Dar alSalam

Al-Ghazali, Al-Ghazali, Abu Hamid, Muhammad Bin Ahmad. 2000. Ihya' 'Ulum al-Din. Kaherah : Dar al-Taqwa li al-Turath.

al-Qaradawi, Yusuf (1993). al-'Ibadah fi al-Islam. Beirut : Muasssah al-Risalah

Belaire, C., \& Young, J. (2000). Influences of Spirituality on Counselor election. Counseling \& Values, 44(3), 189-197.

Benjamin, P., \& Looby, J. (1998). Defining the nature of spirituality in the context of Maslow's and Roger's theories. Counseling and Values, 42, 92-100.

Blando, J. (2006). Spirituality, religion, and counseling. Counseling and Human Development, 39(2), 1-14.

Brian Christoper Post. 2010. Religious and Spiritual Issues in Group Counseling Clients' Beliefs and Preferences. Thesis Degree Master of Science. lowa State University.

Burke, M.T., Hackney, H., Hudson, P., Miranti, J., Watts, G.A., \& Epp, L. (1999) Spirituality, Religion, and CACREP Curriculum Standards, Journal of Counseling \& Development, Volume 77(3), 251-257.

Cornish, Marilyn A.; Wade, Nathaniel G.; Post, Brian C. 2012. Attending to Religion and Spirituality in Group Counseling: Counselors' Perceptions and Practices. Group Dynamics-Theory Research And Practice, 16(2), 122-137. DOI: 10.1037/a0026663.

Corey, G (2003). Issues \& Ethics in the Counseling Profession (6 $6^{\text {th }}$ ed) Pasific Grove, CA:Books/Cole.

Day, J.M. (2010). Religion, Spirituality, and Positive Psychology In Adulthood: A Developmental View. Journal of Adult Development, 17(4), 215-229.

Ee Ah Meng. (2003). Guidance and Counseling II. Second Edition. Shah Alam : Penerbit Fajar Bakti

Hansen,J.C, Rosserberg, R.H, \& Cramer,S.H (1994).Counseling: Theory and Process (5th ed). Boston: Allyn \& Bacon.

Hofmann, L \& Walach, H. (2011). Spirituality and Religiosity in Psychotherapy - a Representative Survey among German Psychotherapist. Psychotherapy Research, 21(2), 179-192.

Hathaway, William L., \& Pargament, Kenneth. I. (1991). The Religious Dimensions of Coping: Implications for Preventions and Promotion. Prevention in Human Sciences, 9(2), 65-92

Keating, A., \& Fretz, B. (1990). Christians' anticipations about counselors in response to counselor descriptions. Journal of Counseling Psychology, 37, 293-296.

Nadiah Elias. 2009. Understanding Cases using the Islamic Perspective. Jurnal PEKAMA. Jilid $5: 51-62$

Maznah Baba dan Zainal Madon. 2003. Individual Counseling, Practical and Effective Guidance. Bentong, Pahang : PTS Publications \& Distributors Sdn. Bhd

Mohd Sabri Mamat, Syed Najmuddin Syed Hassan \& Ab.Halim Tamuri. Daily Ibadah Practice and its Contribution to Youth Emotional Intelligence. Journal of Islamic And Arabic Education 1 (1) 29-40.

Mohd Syukri Kamis. 2010. Islamic Counseling: Questions for Clients during Counseling Session. Paper presented at National Conference Pekama, Universiti Malaysia Terengganu. 
Morrison, J. , Clutter, S. , Pritchett, E. , \& Demmitt, A. (2009). Perceptions of Clients and Counseling Professionals Regarding Spirituality In Counseling. Counseling and Values, 53(3), 183-194.

Mulhim, Ahmad Salim (2004). Makanah al-'Ibadat fi Daw'i al-Quran wa al-Sunnah. Urdun : Dar al-Nafa'is

Nurul Ain Mohd Daud. (2006). Spiritual Aspect in Counseling: Implications towards Counselors) In Md Noor Saper (Editor), Counseling Issues from Islamic Perspective. Kuala Lumpur: Pustaka Salam

Nursaidatul Fasiha Mansur. (2011). Education Faculty Student Perception towards the place of Zikr as a Human Psychological Therapy. Academic Project. Department of Science and Education (Islamic Studies), Universiti Teknologi Malaysia.

Post, Brian C. \& Wade, Nathaniel G, (2014). Client Perspectives about Religion and Spirituality in Group Counseling, Counseling Psychologist, 42 (5), 601-627.

Richards, P.S., \& Bergin, A. E. (1997). A Spiritual Strategy For Counseling And Psychotherapy. Washington, DC: American Psychological Association.

Rose, E. M., Westefeld, J. S., \& Ansley, T. N. (2001). Spiritual Issues in Counseling: Clients' Beliefs and Preferences. Journal of Counseling Psychology, 48, 61-71.

Saenz, Roswitha \& Waldo, Michael (2013). Clients' Preferences Regarding Prayer during Counseling. Psychology of Religion and Spirituality, 5(4), 325-334.

Salasiah Hanin Hamjah \& Noor Shakirah Mat Akhir (2014). Islamic Approach in Counseling, Journal of Religion and Health, 53(1) 279289.

Salasiah Hanin Hamjah. 2010. Method to Overcome Anxiety in Counseling: Analysis from al-Ghazali's Perspective. Jurnal Hadhari 3 (1), 41-57.

Salasiah Hanin Hamjah (2010). Al-Ghazali's Spiritual Guidance and its Relation with Effective Counseling: A Study at PKMAINS Counseling Centre, (Majlis Agama Islam Negeri Sembilan) Jurnal Islamiyyat, 32, 41-62.

Salasiah Hanin Hamjah, Zainab Ismail \& Noor Shakirah Mat Akhir. (2012). Method of Ibadah Application in Counseling. Skudai, Universiti Teknologi Malaysia, Jurnal Teknologi, 59, 87-92.

Sapora Sipon, Ahmad Jazimin Jusoh dan Hapsah Md Yusof. (2002). Individual Counseling. Petaling Jaya : Prentice Hall.

Smith, Daniel J. (2006). Rehabilitation Counselor Willingness to Integrate Spirituality into Client Counseling Sessions. Journal of Rehabilitation. 72(3), 4-11

Souza, Katherine Z. (2002) Spirituality in Counseling: What Do Counseling StudentsTthink About it? Counseling and Values, 46(3), 213217.

Tiffany Nickles. (2011). The Role of Religion and Spirituality in Counseling. A Senior Project submitted in partial fulfillment of the requirements for the Bachelor of Science Degree in Psychology. California Polytechnic State University 